\title{
RESPON FISIOLOGI MINDI (Melia azedarach L.) DAN KEDELAI (Glycine max (L.) Merrill) DALAM AGROFORESTRI SECARA ORGANIK
}

\author{
Physiological Response of Mindi (Melia azedarah L.) and Soybean (Glycine max (L.) Merrill) \\ in Organic Agroforestry
}

\author{
Arum Sekar Wulandari ${ }^{1}$, Aditya Wardani ${ }^{2}$, Nurheni Wijayanto ${ }^{1}$
}

(Diterima Januari 2017/ Disetujui Januari 2020)

\begin{abstract}
Mindi is one of commercial tree species for its timber. Sustainable management of mindi community forest can be obtained by inter-planting the trees with agricultural crop such as soybean. This study aimed to analyze physiological respond of mindi and soybean, which were planted in an organic agroforestry system. The research was done in Conservation Unit for Medicinal Plants at Cikabayan, Bogor Agricultural University (IPB). The first study was about the growth of mindi saplings in monoculture and agroforestry systems (with soybean). The experiment used completely randomized design (CRD). The second study was about the growth of soybean in monoculture and agroforestry systems (with mindi), and used split-plot design. The result show that nutrient uptake of $N, P$, and $K$ in agroforestry system was higher than in monoculture. The increase of nutrient content in agroforestry system led to the higher increase of growth dimensions of mindi tree than the ones in monoculture. The content of soybean chlorophyll planted in agroforestry system was higher than the ones in monoculture. Soybean in agroforestry system had higher nutrient uptake of $N, P$, and $K$ compared to the ones in monoculture. Soybean productivity in monoculture system showed higher result than the ones in agroforestry.
\end{abstract}

Keywords: chlorophyll, monoculture, root, tree dimension, varieties

\section{PENDAHULUAN}

Mindi (Melia azedarach L.) merupakan tanaman cepat tumbuh yang banyak ditemui di Jawa Barat. Mindi juga merupakan tanaman serbaguna karena seluruh bagian tanamannya mulai dari akar, batang, kulit batang, daun, buah dan biji dapat dimanfaatkan. Menurut Khan et al. (2011) kualitas kayu mindi cukup baik sehingga memiliki potensi ekonomi yang tinggi. Mindi yang dikembangkan di Jawa Barat sangat jarang ditemukan ditanam secara monokultur dalam jumlah yang banyak, namun pada umumnya dalam bentuk hutan campuran yang tidak beraturan. Pengelolaan hutan rakyat mindi secara berkelanjutan dapat dilakukan dengan memadukan tanaman pertanian sebagai penyedia pangan bagi masyarakat. Tanaman pertanian yang dapat dikombinasikan dengan mindi salah satunya adalah kedelai (Glycine max L.).

Kedelai merupakan tanaman multiguna karena kegunaannya sebagai pangan, pakan maupun bahan baku industri olahan. Menurut Kamsiati (2006) kandungan protein kedelai lebih tinggi dibandingkan jenis kacang-kacangan lainnya. Produksi kedelai tahun 2015 sebanyak 963.1 ribu ton biji kering, meningkat sebanyak 8.1 ribu ton dibandingkan tahun 2014. Peningkatan produksi kedelai diperkirakan terjadi karena kenaikan produktivitas sebesar 0.18 kuintal/ha meskipun luas panen mengalami penurunan seluas 1800

\footnotetext{
${ }^{1}$ Staf Pengajar Dept. Silvikultur Fakultas Kehutanan IPB

* Penulis korespondensi:

e-mail: rr_arum@yahoo.com

${ }^{2}$ Mahasiswa Pascasarjana PS Silvikultur Tropika, Fakultas Kehutanan IPB
}

ha (BPS 2016). Meskipun terjadi peningkatan baik produksi dan produktivitas, namun ketersediannya belum mencukupi kebutuhan masyarakat. Kebutuhan kedelai total tahun 2012 mencapai 2.2 juta ton. Berdasarkan proyeksi pertumbuhan penduduk dan ratarata konsumsi per kapita per tahun, kebutuhan kedelai di Indonesia mencapai 2.6 juta ton pada tahun 2020 (Harsono 2008).

Menurut Efendi (2010) pola pertanian yang banyak diterapkan saat ini yaitu secara konvensional dengan pengunaan pupuk anorganik dan pestisida kimia yang tinggi. Penanaman kedelai dapat dilakukan secara organik dengan penggunaan input ketersediaan hara dan ketahanan tanaman terhadap organisme pengganggu tanaman (OPT) lebih ramah lingkungan untuk mencapai keseimbangan ekosistem alam. Contohnya: (1) penambahan hara dilakukan dengan menggunakan pupuk organik berupa kompos dan pupuk kendang; dan (2) pengendalian OPT dilakukan dengan menggunakan tanaman yang dapat menghalau datangnya serangga hama. Tanaman pengahalau serangga dapat ditanam di sekeliling pertanaman (misalnya serai wangi), atau dijadikan ekstrak (misalnya ekstrak daun mindi) yang disemprotkan ke tanaman untuk mengendalikan hama tanaman.

Upaya untuk meningkatkan produksi kedelai nasional dapat ditempuh dengan tiga pendekatan yaitu: peningkatan produktivitas, peningkatan intensitas tanam, dan perluasan areal tanam (Eka et al. 2015). Perluasan areal tanam dapat dilakukan salah satunya dengan memanfaatkan sistem agroforestri. Sobari et al. (2012) menyatakan bahwa di dalam sistem agroforestri terjadi proses interaksi atau hubungan timbal balik 
antara satu jenis tanaman dengan lainnya pada lahan yang sama. Penelitian ini bertujuan menganalisis respon fisiologi mindi dan kedelai dalam agroforestri secara organik.

\section{METODE PENELITIAN}

\section{Waktu dan Lokasi Penelitian}

Penelitian dilaksanakan selama 6 bulan, yaitu dari Bulan Januari sampai Juni 2016. Lokasi penelitian di lahan Unit Konservasi Budidaya Biofarmaka Cikabayan Kampus IPB Darmaga seluas $300 \mathrm{~m}^{2}$, dengan koordinat berada pada $106^{\circ} 43$ ”0.81” BT, 6032"51.95” LS.

\section{Bahan dan Alat}

Bahan-bahan yang digunakan dalam penelitian ini adalah tegakan mindi umur 2 tahun, benih kedelai (varietas Anjasmoro, Wilis, Tanggamus), serai wangi, pupuk kandang kambing, pupuk kandang ayam, lolime, dan pupuk hayati rhizobium. Alat-alat yang digunakan adalah cangkul, garpu tanah, pita ukur, timbangan, lux meter, haga hypsometer, kaliper, dan termohigrometer.

\section{Prosedur Penelitian}

\section{Penelitian 1. Pertumbuhan Tanaman Mindi pada Pola Tanam Monokultur dan Agroforestri}

Mindi yang digunakan dalam penelitian ini berumur 2 tahun dengan jarak tanam $2.5 \mathrm{~m}$ x $2.5 \mathrm{~m}$. Pola tanam yang diterapkan pada mindi ialah monokultur dan agroforestri. Pada pola tanam agroforestri, dilakukan penanaman kedelai di antara tegakan mindi. Detail penanaman kedelai pada pola tanam agroforestri dijelaskan pada prosedur penelitian ke-2.

\section{Pengamatan}

Pengambilan data dilakukan terhadap beberapa peubah dimensi tanaman mindi (tinggi dan diameter batang; panjang, kedalaman, dan diameter akar); dan kandungan N, P, K daun mindi. Pengukuran tinggi (m) menggunakan haga hypsometer, mulai dari pangkal batang sampai titik tumbuhnya. Pengukuran diameter batang $(\mathrm{cm})$ menggunakan pita ukur, diukur pada ketinggian $130 \mathrm{~cm}$ di atas pangkal batang mindi. Pengukuran tingi dan diameter batang dilakukan 1 bulan sekali sampai bulan ke-4. Pengukuran akar dilakukan pada awal dan akhir pengamatan (3 bulan pengamatan). Menurut Wijayanto dan Hidayanthi (2012) penggalian akar dilakukan tegak lurus petak, secara bertahap yaitu penggalian sebelah barat terlebih dahulu lalu dilanjutkan pada penggalian di sebelah timur. Penggalian ini dilakukan dengan hati-hati untuk mencegah putusnya akar. Metode penggalian dilakukan dengan menggali di pertengahan larikan dua pohon, penggalian tersebut dihentikan ketika ditemukan akar, apabila masih belum ditemukan akar sampai kedalaman $30 \mathrm{~cm}$, dilanjutkan menggali tanah pada jarak $25 \mathrm{~cm}$ ke arah kanan dan kiri dari penggalian sebelumnya, hal tersebut dilakukan sampai dijumpai akar di dalam permukaan tanah. Pengukuran pertumbuhan akar dilakukan setelah selesai penggalian. Penggalian akar yang telah dilakukan digunakan untuk mengetahui pertumbuhan akar mindi. Akar yang sudah ditemukan ujungnya, diukur panjang dan kedalamannya.

Sampel daun mindi yang digunakan untuk pengukuran kandungan $\mathrm{N}, \mathrm{P}, \mathrm{K}$ diambil secara acak kemudian dikompositkan. Sampel daun mindi yang digunakan sebesar $100 \mathrm{~g}$ daun kering. Analisis kandungan hara daun mindi dilakukan di Laboratorium Pengujian, Departemen Agronomi dan Hortikultura, IPB.

\section{Rancangan Percobaan dan Analisis Data}

Penelitian menggunakan rancangan acak lengkap (RAL) dengan satu faktor, yaitu pola tanam. Pola tanam terdiri atas 2 taraf yaitu mindi yang ditanam secara monokultur dan mindi yang ditanan secara agroforestri (dengan tanaman kedelai). Jumlah mindi pada masingmasing pola tanam adalah 14 tanaman. Data yang diperoleh dari hasil pengukuran dianalisis dengan menggunakan sidik ragam (ANOVA) pada taraf nyata $5 \%$ untuk mengetahui pengaruh perlakuan. Jika: a. Pvalue $>\alpha(0.05)$, maka perlakuan tidak memberikan pengaruh nyata terhadap peubah yang diamati, b. Pvalue $<\alpha(0.05)$, maka perlakuan memberikan pengaruh nyata terhadap peubah yang diamati, dan dilanjutkan dengan Uji Jarak Berganda Duncan.

\section{Penelitian 2. Produktivitas Kedelai pada Pola Tanam Monokultur dan Agroforestri}

\section{Penyiapan Lahan.}

Pengolahan lahan dilakukan 2 minggu sebelum penanaman kedelai. Penyiapan lahan bertujuan membebaskan lahan dari tumbuhan liar dan komponen lain serta memberikan ruang tumbuh untuk tanaman kedelai. Penyiapan lahan meliputi kegiatan pembersihan lahan dan pengolahan lahan. Pembersihan lahan dilakukan dengan menebas semak serta tumbuhan liar dan membersihkannya dari sisa akar tanaman. Tanah kemudian diolah menggunakan cangkul hingga gembur dan rata, dan diikuti dengan pemberian lolime sebanyak $2 \mathrm{~g} / 5 \mathrm{~L}$ sehingga menaikan $\mathrm{pH}$ tanah di lahan percobaan. Ukuran bedengan yang dibuat yaitu $1.2 \mathrm{~m} \mathrm{x} 4 \mathrm{~m}$ dengan jarak antar tanaman mindi dan bedengan adalah $50 \mathrm{~cm}$, sedangkan jarak antar plot dan ulangan adalah $2.5 \mathrm{~m}$. Tanah yang telah dibuat bedengan kemudian dicampur dengan pupuk kandang kambing dengan dosis 12.5 ton/ha (Efendi 2010). Pupuk kandang ayam juga ditambahkan dengan dosis 10 ton/ha (Melati dan Andriyani 2005). Menurut Sudarsono et al. (2013) pupuk kandang kambing dan ayam didiamkan selama 2 minggu sebelum penanaman dengan cara dibenamkan ke tanah agar terdekomposisi.

\section{Persiapan Benih Kedelai.}

Benih kedelai varietas Tanggamus, Wilis, dan Anjasmoro yang digunakan berasal dari Balai Besar Penelitian dan Pengembangan Bioteknologi dan Genetika Cimanggu, Bogor. Umur simpan benih kedelai varietas Tanggamus dan Anjasmoro \pm 3 minggu, sedangkan varietas Wilis \pm 2 minggu. Penyimpanan benih kedelai dilakukan dengan menggunakan 
aluminium foil dan disimpan di dalam ruang dingin dengan suhu $18-20{ }^{\circ} \mathrm{C}$. Ketiga benih tersebut termasuk dalam kelas benih penjenis (breeder seeds). Varietas Anjasmoro merupakan kedelai biji besar sedangkan Tanggamus dan Wilis merupakan kedelai biji sedang. Jumlah benih kedelai yang dibutuhkan \pm 1.000 buah atau \pm 160 gram untuk benih kedelai varietas Anjasmoro, \pm 110 gram untuk Tanggamus, dan \pm 100 gram untuk Wilis. Benih kedelai diinokulasi dengan pupuk hayati yang mengandung konsorsium rhizobium dengan konsentrasi $5 \mathrm{~g} / 40 \mathrm{~kg}$ benih kedelai (Rafiastuti et al. 2012). Pencampuran rhizobium dilakukan dengan cara membasahi benih kedelai dengan air secukupnya, selanjutnya dicampurkan dengan rhizobium hingga melekat secara merata di permukaan benih.

\section{Penanaman Kedelai}

Penanaman dilakukan setelah membuat lubang tanam pada kedalaman 3-4 cm. Jarak tanam antar lubang $40 \mathrm{~cm} \times 20 \mathrm{~cm}$ sehingga terdapat 60 lubang setiap petak. Benih ditanam ke dalam lubang tanam sebanyak 3 benih setiap lubang tanam dan ditutup dengan tanah lapisan permukaan. Pada pola tanam monokultur, dalam satu petakan lahan hanya ditanami dengan tanaman kedelai; sedangkan pada pola tanam agroforestri, tanaman kedelai ditanam di antara tegakan mindi.

\section{Pemeliharaan.}

Penjarangan kedelai dilakukan 2 minggu setelah tanam (MST). Penyulaman dilakukan ketika tanaman berumur 1 MST pada kedelai yang tidak tumbuh atau tumbuh abnormal. Kegiatan pembumbunan dilakukan bersamaan dengan penyulaman tersebut. Penyiangan dilakukan secara berkelanjutan sesuai dengan kondisi lapangan. Pengendalian OPT dilakukan dengan menanam tanaman serai wangi yang berada di sekeliling petakan penelitian (Kusheryani dan Aziz 2006). Tanaman serai wangi ditanam dengan jarak $100 \mathrm{~cm} \mathrm{x}$ $100 \mathrm{~cm}$ di sekeliling petak kedelai. Pengendalian hayati dilakukan juga dengan ekstrak daun mindi. Pembuatan ekstrak daun mindi mengacu pada Bukhari (2011) tentang pembuatan ekstrak daun mimba. Daun mindi segar dengan berat $100 \mathrm{~g}$ dihaluskan dan dilarutkan ke dalam $1000 \mathrm{~mL}$ air. Ekstrak daun mindi sebanyak 200 $\mathrm{mL}$ kemudian dicampur dengan $800 \mathrm{~mL}$ air. Pengendalian hama pada tanaman kedelai dilakukan dengan menyemprotkan ekstrak daun mindi pada fase vegetatif dan generatif. Penyemprotan dilakukan seminggu sekali pada pagi hari.

\section{Pengamatan}

Peubah yang diamati adalah produksi biji kedelai, pengukuran kandungan klorofil daun kedelai; dan serapan hara daun kedelai. Pemanenan kedelai dilakukan saat polong telah kehilangan warna hijaunya $\pm 90 \%$, batang-batangnya sudah kering, dan sebagian daun-daunnya sudah kering dan rontok, serta biji telah mengeras (Jufri 2006). Produksi kedelai yang diamati adalah jumlah polong isi per tanaman, bobot biji per petak, dan perkiraan produksi/ha.

Analisis fisiologi terhadap daun kedelai yang dilakukan terdiri atas analisis klorofil dan hara tanaman. Analisis kandungan klorofil (klorofil a, klorofil b, klorofil total) dan kandungan hara daun $(\mathrm{N}, \mathrm{P}, \mathrm{K})$ menggunakan sampel daun yang telah membuka sempurna yaitu pada umur 7 MST. Pengambilan sampel daun dilakukan pada daun ke-3 atau ke-4 dari atas, jumlah sampel daun yang digunakan sekitar 3-5 helai. Daun yang dijadikan sempel tersebut dimasukkan dalam plastik dan disimpan ke cool box, selanjutnya dianalisis di laboratorium. Serapan hara dihitung dengan menggunakan rumus (Agung dan Rahayu 2004):

Serapan hara (g/tanaman $)=$ bobot kering daun $x$ kandungan hara

\section{Rancangan Percobaan dan Analisis Data.}

Penelitian menggunakan rancangan acak kelompok petak terbagi (split plot design). Petak utamanya adalah pola tanam, yang terdiri atas 2 taraf yaitu monokultur kedelai dan agroforestri kedelai-mindi. Anak petaknya adalah varietas kedelai yang terdiri atas 3 taraf yaitu Anjasmoro, Tanggamus, dan Wilis. Setiap perlakuan diulang sebanyak 3 kali. Analisis data dilakukan seperti pada penelitian ke-1.

\section{HASIL DAN PEMBAHASAN}

\section{Respon Fisiologi terhadap Pertumbuhan Mindi}

Kandungan hara $(\mathrm{N}, \mathrm{P}, \mathrm{K})$ daun mindi menunjukkan peningkatan selama perlakuan pola tanam (Tabel 1). Peningkatan kandungan hara yang lebih tinggi ditemukan pada pola tanam agroforestri mindikedelai dibandingkan dengan pola tanam monokultur mindi. Kandungan hara $\mathrm{N}$ daun mindi yang ditanam dengan pola tanam agroforestri meningkat sebesar $8.66 \%$ jika dibandingkan dengan mindi monokultur, sedangkan kandungan hara K sebesar $14.14 \%$. Hal sebaliknya terjadi pada kandungan hara $\mathrm{P}$ yang lebih tinggi pada monokultur mindi dibandingkan dengan agroforestri mindi-kedelai. Menurut Rina (2015) unsur $\mathrm{N}$ dibutuhkan dalam jumlah besar dikarenakan menyusun $1-5 \%$ berat tubuh tanaman. Unsur $\mathrm{K}$ yang terkandung pada tanaman sekitar $0.5-6 \%$. Fosfor $(\mathrm{P})$ termasuk hara makro yang penting untuk pertumbuhan tanamanan namun kandungannya di dalam tanaman lebih rendah dibandingkan dengan unsur $\mathrm{N}$ dan $\mathrm{K}$ (Novriani 2010). Kadar $\mathrm{P}$ dalam tanaman berkisar $0.14-0.25 \%$.

Tabel 1 Kandungan unsur hara mindi yang ditanam dengan pola tanam monokultur dan agroforestri di awal dan akhir pengamatan ( 3 bulan)

\begin{tabular}{cccc}
\hline \multirow{2}{*}{ Unsur hara } & \multirow{2}{*}{ Awal pengamatan } & \multicolumn{2}{c}{ Akhir pengamatan } \\
\cline { 3 - 4 } & & Monokultur & Agroforestri \\
\hline N Total (\%) & 4.04 & 4.33 & 4.68 \\
P Total (\%) & 0.25 & 0.39 & 0.36 \\
K Total (\%) & 1.98 & 2.16 & 2.44 \\
\hline
\end{tabular}


Dimensi tanaman menjadi parameter penting untuk mengetahui interaksi dan persaingan yang ada pada suatu lahan dalam sistem agroforestri. Peubah dimensi mindi yang diamati adalah tinggi, diameter, dan akar. Mindi yang diamati berada pada pola tanam monokultur dan agroforestri.

Pertambahan tinggi dan diameter mindi pada pola tanam agroforestri lebih besar dibandingkan dengan pola monokultur (Tabel 2). Adanya tanaman kedelai menyebabkan keadaan tempat tumbuh menjadi lebih baik (Wijayanto \& Hidayanthi 2012). Adanya akar dari tanaman semusim membuat aerasi dan drainase tanah lebih baik sehingga memudahkan mindi menyerap unsur hara sehingga tumbuh lebih baik. Kegiatan pemupukan untuk tanaman kedelai di bawah tegakan mindi menyebabkan penambahan ketersediaan unsur hara sehingga kandungan unsur hara menjadi lebih besar dibandingkan dengan pola tanam monokultur.

Akar memberikan pengaruh terhadap tanaman dalam penyerapan air dan unsur hara. Akar mudah tumbuh pada tanah dengan jumlah pori-pori yang banyak. Persaingan pertumbuhan akar menjadi kendala dalam penerapan sistem agroforestri. Menurut Zamora et al. (2007) diameter akar dan panjang akar merupakan parameter tumbuhan yang menunjukkan interaksi di bawah tanah. Akar pada pola tanam monokultur lebih panjang dibandingkan dengan agroforestri (Tabel 2). Hal ini diduga karena akar pada monokultur memperpanjang jangkauan untuk mendapatkan unsur hara. Kegiatan pemeliharaan pada pola tanam agroforestri seperti pemupukan pada tanaman semusim menyebabkan penambahan unsur hara di sekitar tanaman mindi.

Perbedaan yang nyata terdapat pada pertambahan kedalaman akar (Tabel 2). Pertambahan kedalaman akar mindi pada plot monokultur lebih tinggi dibandingkan dengan plot agroforestri. Young (2002) menyebutkan bahwa pertumbuhan akar lateral pada plot monokultur yang cenderung ke dalam tanah menunjukkan bahwa unsur hara yang ada di plot tersebut terdapat di tanah yang lebih dalam. Kegiatan pemupukan pada tanaman kedelai menyebabkan akar lateral pada plot agroforestri diduga tidak tumbuh ke dalam.

Akar pada plot monokultur berdiameter lebih kecil jika dibandingkan dengan plot agroforestri. Perkembangan pertambahan diameter yang lebih besar pada pola tanam agroforestri diakibatkan meningkatnya kebutuhan hara. Pemupukan yang dilakukan pada tanaman kedelai hanya di awal penanaman menyebabkan unsur hara yang tersedia untuk pertumbuhan mindi semakin kecil. Mindi dalam pertumbuhannya membutuhkan unsur hara dan air. Rusdiana et al. (2000) menyebutkan bahwa diameter akar meningkat disebabkan karena tanaman tersebut masih memanfaatkan nutrisi yang ada.

\section{Respon Fisiologi terhadap Produksi Kedelai}

Proses metabolisme yang penting dalam tumbuhan salah satunya adalah proses fotosintesis. Fotosintesis terjadi di dalam kloroplas yang mengandung klorofil dan berfungsi menyerap cahaya matahari. Cahaya merupakan faktor utama dalam proses fotosintesis. Rendahnya cahaya matahari yang diterima oleh kedelai pada pola tanam agroforestri menyebabkan perbedaan kandungan klorofil pada kedelai.

Berdasarkan hasil analisis ragam pola tanam dan varietas memberikan pengaruh yang berbeda nyata terhadap respon fisiologi kedelai. Interaksi dari pola tanam dan varietas tidak berbeda nyata terhadap respon fisiologi kedelai (Tabel 3).

Kandungan klorofil a, klorofil b, dan total klorofil pada pola tanam agroforestri lebih tinggi dibandingkan dengan monokultur (Tabel 4). Menurut Muhuria et al. (2006) kandungan klorofil a dan b meningkat daripada keadaan normal pada kedelai dengan intensitas cahaya $50 \%$. Kondisi intesitas cahaya matahari yang rendah pada pola tanam agroforestri menyebabkan tanaman

Tabel 2 Pertambahan dimensi mindi yang ditanan dengan pola tanam monokultur dan agroforestri pada setiap bulan pengamatan

\begin{tabular}{lccc}
\hline \multicolumn{1}{c}{ Peubah } & Uji F & Pola tanam & Agroforestri \\
\cline { 2 - 4 } Pertambahan tinggi pohon (m) & & Monokultur & $2.82^{\mathrm{a}}$ \\
$\quad$ Bulan 1 & $*$ & $0.93^{\mathrm{b}}$ & $0.68^{\mathrm{a}}$ \\
Bulan 2 & $*$ & $0.32^{\mathrm{b}}$ & $0.54^{\mathrm{a}}$ \\
$\quad$ Bulan 3 & $*$ & $0.32^{\mathrm{b}}$ & $1.71^{\mathrm{a}}$ \\
Pertambahan diameter pohon (mm) & & $1.41^{\mathrm{a}}$ & $0.32^{\mathrm{a}}$ \\
$\quad$ tn & $0.18^{\mathrm{a}}$ & $0.31^{\mathrm{a}}$ \\
$\quad$ tn & $0.14^{\mathrm{b}}$ & $41.00^{\mathrm{a}}$ \\
Bulan 1 & $*$ & $56.43^{\mathrm{a}}$ & $3.57^{\mathrm{b}}$ \\
Pertambahan panjang akar (cm) & tn & $23.36^{\mathrm{a}}$ & $0.72^{\mathrm{a}}$ \\
Pertambahan kedalaman akar (cm) & $*$ & $0.43^{\mathrm{b}}$ & \\
\hline
\end{tabular}

(tn) : tidak berbeda nyata; $(*)$ : berbeda nyata pada taraf uji 5\%, angka-angka pada kolom yang sama yang diikuti oleh huruf yang sama tidak berbeda nyata pada taraf uji $5 \%$ (uji selang berganda Duncan).

Tabel 3 Rekapitulasi hasil analisis ragam kandungan klorofil kedelai yang diberi perlakuan pola tanam dan varietas

\begin{tabular}{llccc} 
& \multicolumn{1}{c}{ Peubah } & Pola tanam & Varietas & Interaksi \\
\cline { 3 - 5 } & & $(\mathrm{P})$ & $(\mathrm{V})$ & $(\mathrm{PXV})$ \\
\hline 1. & Kandungan klorofil a & $*$ & $*$ & tn \\
2. & Kandungan klorofil b & $*$ & $*$ & tn \\
3. & Kandungan total klorofil & $*$ & $*$ & tn \\
\hline
\end{tabular}

(tn) : tidak berbeda nyata; $(*)$ : berbeda nyata pada taraf uji $5 \%$. 
beradaptasi dengan memiliki kompleks pemanenan cahaya yang lebih tinggi dibandingkan pada tanaman yang mendapatkan cahaya penuh.

Perlakuan pola tanam memberikan pengaruh yang nyata terhadap peubah produksi kedelai (Tabel 5). Secara keseluruhan pola tanam monokultur memberikan pengaruh yang baik bagi produksi kedelai bila dibandingkan dengan agroforestri.

Kedelai mampu tumbuh pada kondisi suhu yang beragam. Menurut Subantoro (2013) proses perkecambahan benih kedelai memerlukan suhu sekitar $30{ }^{\circ} \mathrm{C}$. Rata-rata suhu pada plot monokultur adalah $31{ }^{\circ} \mathrm{C}$ dan lebih tinggi dibandingkan dengan plot agroforestri sebesar $29^{\circ} \mathrm{C}$. Curah hujan berperan dalam pertumbuhan kedelai hal ini disebabkan air mempunyai peran penting sebagai pelarut hara, translokasi hara dan fotosintesis. Menurut Prihatman (2000) tanaman kedelai mampu menghasilkan produksi yang optimal dengan curah hujan 100-200 mm/bulan. Curah hujan melebihi $300 \mathrm{~mm} /$ bulan selama musim tanam kedelai.

Salah satu faktor utama yang mempengaruhi pertumbuhan tanaman adalah cahaya. Intensitas cahaya yang tinggi menyebabkan bertambah tinggi pula kecepatan fotosintesis tanaman. Intensitas cahaya untuk plot monokultur adalah 400 lux lebih tinggi dibandingkan dengan plot agroforestri sebesar 175 lux. Keberadaan tanaman pelindung dari jenis tanaman tahunan (pohon) akan mengurangi tingkat radiasi yang diterima oleh tanaman sela khususnya dari jenis tanaman semusim yang tumbuh di antara tanaman pelindung.

Jumlah polong isi per tanaman, bobot biji per petak dan hasil (ton/ha) pada pola tanam monokultur berbeda nyata dibandingkan dengan agroforestri. Jumlah polong yang rendah pada agroforestri dapat disebabkan kurangnya cahaya yang diterima oleh kedelai sehingga mempengaruhi kegiatan fotosintesis dan menyebabkan berkurangnya hasil fotosintat. Irdiawan dan Rahmi (2002) menyatakan bahwa proses pengisian polong memerlukan sinar matahari yang maksimal dan air yang cukup selama beberapa waktu.

Menurut Sopandie et al. (2005) tanaman yang ternaungi melakukan adaptasi dengan cara mengefisiensikan penangkapan cahaya yang lebih besar dengan meningkatkan jumlah kloroplas dan kandungan pigmen dalam kloroplas. Kandungan klorofil a salah satunya dipengaruhi oleh faktor cahaya, inhibitor plastid, interaksi antara cahaya dan inhibitor. Klorofil b hanya dipengaruhi oleh faktor cahaya (Kisman et al. 2007). Hal tersebut menunjukkan bahwa cahaya berperan penting terhadap kandungan klorofil pada tanaman kedelai.

Kandungan klorofil a, klorofil b, dan total klorofil pada varietas Wilis lebih tinggi bila dibandingkan kedua varietas yang lain. Rata-rata kandungan klorofil kedelai varietas Tanggamus lebih rendah dibandingkan dengan Wilis dan Anjasmoro (Tabel 6). Jumlah klorofil yang semakin tinggi menyebabkan peningkatan efisiensi penangkapan cahaya untuk fotosintesis tanaman (Purwoko 2003). Klorofil a dan b pada tanaman digunakan dalam proses fotosintesis. Hasil (ton/ha) kedelai untuk varietas Wilis memiliki nilai yang tinggi dan varietas Tanggamus memiliki nilai yang rendah (Tabel 7).

Persentase serapan hara pada kedelai monokultur dan agroforestri berbeda-beda (Gambar 1). Menurut Hartoyo (2014) tanaman yang kurang cahaya dapat mempengaruhi pertumbuhan akar serta menunjukkan

Tabel 4 Kandungan klorofil tanaman kedelai pada pola tanam monokultur dan agroforestri

\begin{tabular}{llcc}
\hline & \multicolumn{1}{c}{ Peubah } & \multicolumn{2}{c}{ Pola tanam } \\
\cline { 3 - 4 } & Kandungan klorofil a & Monokultur & Agroforestri \\
\hline 1. & Kandungan klorofil b & $2.53^{\mathrm{b}}$ & $3.13^{\mathrm{a}}$ \\
2. & $0.98^{\mathrm{b}}$ & $1.26^{\mathrm{a}}$ \\
3. & Kandungan total klorofil & $3.51^{\mathrm{b}}$ & $4.39^{\mathrm{a}}$ \\
\hline
\end{tabular}

Angka-angka pada baris yang sama tidak berbeda nyata pada taraf uji 5\% (uji selang berganda Duncan).

$\underline{\text { Tabel } 5 \text { Pengaruh pola tanam terhadap produksi kedelai }}$

\begin{tabular}{llrr}
\hline & \multicolumn{1}{c}{ Peubah } & \multicolumn{2}{c}{ Pola tanam } \\
\cline { 3 - 4 } & & Monokultur & Agroforestri \\
\hline 1. & Jumlah polong isi/tanaman & $47.90^{\mathrm{a}}$ & $10.73^{\mathrm{b}}$ \\
2. & Bobot biji/petak (g) & $341.40^{\mathrm{a}}$ & $49.57^{\mathrm{b}}$ \\
3. & Hasil (ton/ha) & $0.71^{\mathrm{a}}$ & $0.10^{\mathrm{b}}$ \\
\hline
\end{tabular}

Angka-angka pada baris yang sama tidak berbeda nyata pada taraf uji 5\% (uji selang berganda Duncan).

Tabel 6 Kandungan klorofil pada beberapa varietas kedelai

\begin{tabular}{llccc}
\hline & \multicolumn{1}{c}{ Peubah } & \multicolumn{2}{c}{ Varietas } & Anjasmoro \\
\cline { 3 - 5 } & & Tanggamus & Wilis & $2.89^{\mathrm{ab}}$ \\
\hline 1. & Kandungan klorofil a & $2.39^{\mathrm{b}}$ & $3.22^{\mathrm{a}}$ & $1.18^{\mathrm{a}}$ \\
2. & Kandungan klorofil b & $0.95^{\mathrm{b}}$ & $1.26^{\mathrm{a}}$ & $4.07^{\mathrm{ab}}$ \\
\hline
\end{tabular}

Angka-angka pada baris yang sama tidak berbeda nyata pada taraf uji 5\% (uji selang berganda Duncan).

Tabel 7 Produksi biji pada beberapa varietas kedelai

\begin{tabular}{|c|c|c|c|c|}
\hline \multirow{2}{*}{\multicolumn{2}{|c|}{ Peubah }} & \multicolumn{3}{|c|}{ Varietas } \\
\hline & & Tanggamus & Wilis & Anjasmoro \\
\hline 1. & Jumlah polong isi/tanaman & $28.12^{\mathrm{a}}$ & $33.50^{\mathrm{a}}$ & $26.33^{a}$ \\
\hline 2. & Bobot biji/petak (g) & $131.50^{\mathrm{b}}$ & $251.60^{\mathrm{a}}$ & $203.35^{\mathrm{a}}$ \\
\hline 3. & Hasil (ton/ha) & $0.27^{\mathrm{b}}$ & $0.53^{\mathrm{a}}$ & $0.43^{\mathrm{a}}$ \\
\hline
\end{tabular}

Angka-angka pada baris yang sama tidak berbeda nyata pada taraf uji 5\% (uji selang berganda Duncan). 
gejala etiolasi. Pertumbuhan akar yang terhambat pada pola tanam agroforestri diduga menghambat penyerapan unsur hara pada tanaman tersebut. Serapan hara N, P, dan $\mathrm{K}$ oleh kedelai lebih tinggi pada pola tanam agroforestri dibandingkan dengan monokultur. Hal ini diakibatkan adanya persaingan dengan tanaman kehutanan, sehingga kedelai meningkatkan penyerapan unsur hara untuk pertumbuhannya (Hani 2015).

Gambar 1 menunjukkan bahwa serapan hara N pada kedelai monokultur tertinggi adalah varietas Wilis yang tidak jauh berbeda dengan varietas Anjasmoro, sedangkan varietas Tanggamus memiliki serapan hara $\mathrm{N}$ terendah. Serapan hara P kedelai pola tanam monokultur memiliki nilai yang sama pada ketiga varietas. Varietas Anjasmoro memiliki serapan hara $\mathrm{K}$ yang tinggi dibandingkan dengan varietas Wilis dan Tanggamus. Serapan hara N dan P pada kedelai agroforestri tertinggi adalah varietas Tanggamus. Varietas Anjasmoro memiliki nilai serapan hara $\mathrm{K}$ yang tinggi bila dibandingkan dengan kedua varietas yang lainnya (Gambar 1). Unsur hara N lebih banyak diserap oleh kedelai dibandingkan dengan unsur hara yang lain. Menurut Bhattacharyya et al. (2008) efisiensi penyeraan unsur hara $\mathrm{N}$ lebih tinggi pada kedelai.

Penanaman kedelai secara organik pada tahun pertama belum mampu memberikan hasil yang maksimal. Produktivitas kedelai pada pola tanam monokultur dan agroforestri dengan varietas yang digunakan menunjukkan hasil yang lebih rendah dibandingkan deskripsi yang digunakan (Tabel 8). Menurut Melati et al. (2008) ketersediaan hara dari pupuk organik lebih lambat akibat perlunya proses dekomposisi. Menurut Eghball dan Power (1999) hanya $20 \%$ dari kandungan $\mathrm{N}$ pupuk kandang sapi yang telah dikomposkan tersedia pada tahun pertama aplikasi

Tabel 8 Produktivitas beberapa varietas kedelai

\begin{tabular}{lcc|c}
\hline & \multicolumn{3}{c}{ Produktivitas (ton/ha) } \\
\cline { 2 - 4 } & Tanggamus & Wilis & Anjasmoro \\
\hline Monokultur & 0.51 & 0.90 & 0.72 \\
\hline Agroforestri & 0.03 & 0.15 & 0.13 \\
\hline $\begin{array}{l}\text { Puslittan } \\
(2016)\end{array}$ & 1.22 & 1.60 & 2.03 \\
\hline
\end{tabular}

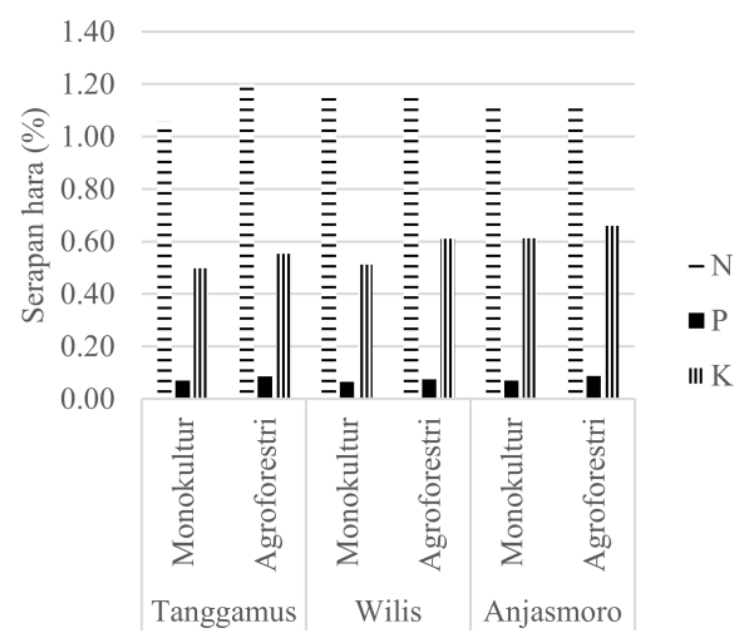

Gambar 1 Serapan hara kedelai yang diberi perlakuan pola tanam dan varietas pupuk. Hal ini mengindikasikan bahwa $80 \%$ sisanya dapat tersedia pada penanaman berikutnya dengan asumsi tidak ada kehilangan melalui pencucian.

\section{SIMPULAN DAN SARAN}

\section{Simpulan}

Kandungan hara $\mathrm{N}$ dan $\mathrm{K}$ daun mindi yang ditanam dengan pola tanam agroforestri (dengan tanaman kedelai) lebih besar dibandingkan dengan monokultur, sedangkan kandungan $\mathrm{P}$ daun mindi lebih tinggi pada daun mindi yang ditanam secara monokultur dibandingkan dengan agroforestri. Dimensi mindi (tinggi, diameter batang, diameter akar) yang ditanam dengan pola tanam agroforestri lebih tinggi dibandingkan dengan monokultur.

Kedelai yang ditanam secara organik dengan pola tanam monokultur memiliki kandungan klorofil lebih tinggi dibandingkan dengan kedelai agroforestri (dengan tanaman mindi). Kedelai varietas Wilis memiliki kandungan klorofil lebih tinggi dibandingkan dengan varietas Tanggamus dan Anjasmoro. Serapan hara $\mathrm{N}, \mathrm{P}$, dan $\mathrm{K}$ pada kedelai yang ditanam dengan pola tanam agroforestri lebih tinggi dibandingkan dengan kedelai monokultur. Produktivitas kedelai yang ditanam dengan pola tanam monokultur lebih tinggi dibandingkan dengan kedelai agroforestri (dengan tanaman mindi).

\section{Saran}

Penelitian sejenis perlu diujicobakan pada jarak tanam yang berbeda antara tanaman mindi dengan kedelai. Kegiatan pemangkasan yang rutin perlu dilakukan mengingat tajuk mindi yang lebat sehingga kedelai di bawah tegakan mindi tidak kekurangan sinar matahari.

\section{DAFTAR PUSTAKA}

Agung T, Rahayu AY. 2004. Analisis efisiensi serapan $\mathrm{N}$, pertumbuhan dan hasil beberapa kultivar kedelai unggul baru dengan cekaman kekeringan dan pemberian pupuk hayati. Agrosains 6(2):7074.

[BPS] Badan Pusat Statistik. 2016. Produksi padi, jagung dan kedelai. [internet]. [Diunduh 2016 Mar 1]. Tersedia pada: http://bps.go.id.

Bhattacharyya R, Kundu S, Prakash V, Gupta HS. 2008. Sustainability under combined application of mineral and organic fertilizers in a rainferd soybeasn-whaet system of India Himalayas. Europ J Agron. 28(2008):33-46.

Bukhari. 2011. Efektifitas ekstrak daun mimba terhadap pengendalian hama Plutella xylostella pada tanaman kedelai. Journal Sains Riset 1(1):1-19.

Efendi. 2010. Peningkatan pertumbuhan dan produksi kedelai melalui kombinasi pupuk organik lamtorogung dengan pupuk kandang. Jurnal Floratek 5(1):65-73. 
Eghball B, Power JF. 1999. Phosphorus and nitrogen based manure and compost application: corn application and soil phosphorus. Soil Sci Soc Am J. 63:895-901.

Eka A, Hanafiah DS, Nuriadi I. 2015. Respon morfologis dan fisiologis beberapa varietas kedelai (Glycine max L. Merrill) di tanah masam. Jurnal Online Agroteknologi 3(2):507-514.

Hani A. 2015. Produktivitas kedelai pada pola agroforestri nyamplung (Callophylum inophylum) di lahan pantai berpasir Pangandaran, Jawa Barat. Jurnal Silvikultur Tropika 6(2):7882.

Hartoyo APP, Wijayanto N, Budi SW. Respon fisiologi dan produksi kedelai (Glycine max (L.) Merrill) toleran naungan berbasiskan agroforestri sengon (Paraserianthes falcataria (L.) Nielsen). Jurnal Silvikultur Tropika 5(2):84-90.

Harsono A. 2008. Strategi pencapaian swasembada kedelai melalui perluasan areal tanam di lahan kering masam. Iptek Tanaman Pangan 26(2):244-257.

Irdiawan R, Rahmi A. 2002. Pengaruh jarak tanam dan pemberian bokhasi pupuk kandang ayam terhadap pertumbuhan dan hasil kacang tanah (Arachis hypogea L.). Jurnal Agrifor. 1(2):31-36.

Kamsiati. 2006. Diversifikasi pengolahan kedelai dalam rangka peningkatan konsumsi kacang-kacangan di Kalimantan Tengah. [internet]. [Diunduh 2016 Jan 01]. Tersedia pada http://kalteng.litbang.deptan.go.id/ind/images/da ta/diversifikasi-kedelai.pdf/.

Khan AV, Khan AA, Shukla I. 2008. In vitro antibacterial potential of Melia azedarach crude leaf extracts against some human pathogenic bacterial strains. Ethnobotanical Leafflets 12(1):439-445.

Kisman, Khumaida N, Trikoesoemaningtyas, Sobir, Sopandie D. 2007. Karakter morfo-fisiologi daun, penciri adaptasi kedelai terhadap intensitas cahaya rendah. Bul Agron 35(2):96-102.

Kusheryani I, Aziz SA. 2006. Pengaruh jenis tanaman penolak organisme pengganggu tanaman terhadap pertumbuhan dan produksi tanaman kedelai (Glycine max (L.) Merr) yang diusahaan secara organik. Bul Agron. 34(1):39- 45.

Melati M, Andriyani W. 2005. Pengaruh pupuk kandang ayam dan pupuk hijau Calopogonium mucunoides terdahap pertumbuhan dan produksi kedelai panen muda yang dibudidayakan secara organik. Bul Agron. 33(2):8-15.

Melati M, Asiah A, Rianawati D. 2008. Aplikasi pupuk organik dan residunya untuk produksi kedelai panen muda. Bul Agron. 36(3):204-213.
Muhuria L. Tyas KN, Khumaida N, Trikoesoemaningtyas, Sopandie D. 2006. Adaptasi tanaman kedelai terhadap intensitas cahaya rendah: karakter daun untuk efisiensi penangkapan cahaya. Bul Agron. 34(3):133-140.

Novriani. 2010. Alternatif pengelolaan unsur hara P (Fosfor) padaa budidaya jagung. Agronobis 2(3):42-49.

Prihatman K. 2000. Budidaya Pertanian Kedelai (Glycine $\max$ L.) [editorial]. Jakarta (ID): Sistim Informasi Manajemen Pembangunan di Pedesaan, Proyek PEMD, Bappenas.

Purwoko. 2003. Pengaruh naungan paranet terhadap sifat toleransi tanaman talas (Colocasia esculenta (L.) Schott). Ilmu Pertanian 10(2):17-25.

Rina D. 2015. Manfaat unsur N, P, dan K bagi tanaman. [internet]. [diunduh 2016 Nov 28]. Tersedia pada:http://kaltim.litbang.pertanian.go.id/ind/ind ex.php?option=com_content\&view=article\&id= 707:manfaat-unsur-n-p-dan-k-bagitanaman\&catid=26:lain\&Itemid $=59$.

Rusdiana O, Fakuara Y, Kusmana C, Hidayat Y. 2000. Respon pertumbuhan akar tanaman sengon (Paraserianthes falcataria) terhadap kepadatan dan kandungan air tanah podsolik merah kuning. Jurnal Manajemen Hutan Tropika 6(2):43-53.

Subantoro R. 2013. Pengaruh berbagai metode pengujian vigor terhadap pertumbuhan benih kedelai. Jurnal Ilmu-ilmu Pertanian 9(1):48-60.

Sudarsono AW, Melati M, Aziz SA. 2013. Pertumbuhan, serapan hara, dan hasil kedelai organik melalui aplikasi pupuk kandang sapi. J Agron Indonesia. 41(3):202-208.

Sobari L, Sakiroh, Purwanto EH. 2012. Pengaruh jenis tanaman penaung terhadap pertumbuhan dan persentase tanaman berbuah pada kopi arabika varietas kartika 1. Buletin RISTRI 3(3):217-222.

Sopandie D, Trikoesoemaningtyas, Khumaida N. 2005. Fisiologi, genetik dan molekular adaptasi kedelai terhadap intensitas cahaya rendah : pengembangan varietas unggul kedelai sebagai tanaman sela [laporan akhir penelitian Hibah Penelitian Tim Pasca Sarjana Angkatan II]. Bogor (ID): Lembaga Penelitian dan Pengabdian Masyarakat, Institut Pertanian Bogor.

Wijayanto N, Hidayanthi D. 2012. Dimensi dan sistem perakaran tanaman sentang (Melia excelsa Jack) di lahan agroforestri. Jurnal Silvikultur Tropika 3(3):196-202.

Zamora DS, Jose S, Nair PKR. 2007. Morphological plasticity of cotton roots in response to interspecific competition with pecan in an alley cropping system in the Southern United States. Agrofo Syst. 69(1):107-116. 